\title{
PENGUASAAN KETERAMPILAN BERTANYA DASAR DI TK BAITURRAHMAN
}

\author{
Indriyani S. ${ }^{1}$; Rohita ${ }^{1}$ \\ ${ }^{1}$ Program Studi Pendidikan Guru Pendidikan Anak Usia Dini, Fakultas Psikologi dan Pendidikan, \\ Universitas Al-Azhar Indonesia, Jalan Sisingamangaraja, Kebayoran Baru, Jakarta Selatan 12110 \\ Penulis untuk Korespondensi/E-mail: rohita@uai.ac.id
}

\begin{abstract}
Abstrak - Penelitian ini bertujuan untuk menggambarkan penguasaan keterampilan bertanya guru di TK Baiturrahman. Penelitian ini berupa penelitian kualitatif dengan pendekatan deskriptif. Sumber data pada penelitian ini ialah guru kelas kelompok A dan guru kelas kelompok B TK Baiturrahman. Teknik pengumpulan data yang digunakan ialah wawancara, observasi dan dokumentasi. Analisis yang digunakan pada penelitian ini adalah analisis data kualitatif. Adapun indikator penguasaan keterampilan bertanya meliputi keterampilan bertanya dasar, keterampilan bertanya lanjutan, jenisjenis pertanyaan serta teknik-teknik bertanya. Hasil penelitian menunjukan bahwa guru TK Baiturrahman lebih menguasai keterampilan bertanya dasar dan keterampilan lanjutan, sedangkan jenis-jenis pertanyaan dan teknik-teknik bertanya guru TK Baiturrahman belum dikuasai.
\end{abstract}

Kata Kunci: Keterampilan Bertanya, Guru TK.

Abstract - This study aims to describe the mastery of the teacher's asking skills at Baiturrahman Kindergarten. This research is a qualitative research with a descriptive approach. The data source for this researcher is the group A teacher and group B TK Baiturrahman class teacher. Data collection techniques used are interviews, observation and documentation. The analysis used in this study is qualitative data analysis. The indicator of mastery of question skills includes basic questioning skills, advanced questioning skills, types of questions and asking techniques. The results showed that Baiturrahman kindergarten teachers were better at mastering basic questioning skills and advanced skills, while the types of questions and techniques asked by the Baiturrahman kindergarten teachers were not mastered yet.

Keywords: Questioning skills, kindergarten teacher

\section{PENDAHULUAN}

$\mathrm{P}$ roses pembelajaran merupakan interaksi yang dilakukan antara guru dengan anak dalam situasi pendidikan atau pengajaran untuk mewujudkan tujuan yang ditetapkan. Guru memegang kunci utama bagi peningkatan mutu pendidikan. Djamarah (2010: 37) berpendapat bahwa tugas guru sebagai profesi menuntut guru untuk mengembangkan profesionalitas diri sesuai perkembangan ilmu pengetahuan dan teknologi. Undang-Undang Nomor 14 Tahun 2005 tentang Guru dan Dosen Pasal 1 ayat (1) menyatakan bahwa guru adalah pendidik profesional dengan tugas utama mendidik, mengajar, membimbing, mengarahkan, melatih, menilai, dan mengevaluasi siswa pada pendidikan anak usia dini, pendidikan dasar, dan pendidikan menengah. Guru sebagai tenaga profesional harus memiliki kompetensi keguruan.

Salah satu kompetensi yang perlu dimilki adalah kompetensi pedagogik, yang di dalamnya meliputi kemampuan guru dalam mengelola pembelajaran anak. Guru sebagai komponen pendidikan dan pengajaran di sekolah menjalankan tugas dan fungsinya di dalam proses pembelajaran atas dasar keterampilan mengajar yang dikuasainya. Menurut Sukirman (2012: 225), keterampilan dasar mengajar merupakan bentuk perilaku atau keterampilan yang bersifat khusus dan juga mendasar yang harus dimiliki guru sebagai modal dasar untuk melaksanakan tugas-tugas pembelajaran secara profesional. 
Dari penjelasan di atas keterampilan dasar megajar harus dimiliki oleh guru kelas sebagai modal dasar untuk melaksanakan kegiatan di dalam kelas secara profesional. Keterampilan dasar mengajar merupakan kumpulan kemampuan yang harus dimiliki oleh guru. Menurut Rusman (2011: 80), ada sembilan keterampilan dasar mengajar guru yang sangat berperan dan menentukan kualitas pembelajaran, diantaranya keterampilan membuka pelajaran, keterampilan bertanya, keterampilan memberi penguatan, keterampilan mengadakan variasi, keterampilan menjelaskan, keterampilan membimbing diskusi kelompok kecil, keterampilan mengelola kelas, keterampilan pembelajaran perseorangan, dan keterampilan menutup pembelajaran. Tugas guru sebagai tenaga profesional dituntut menguasai keterampilan dasar mengajar untuk membimbing anak memenuhi standar kompetensi yang ditetapkan dalam standar pendidikan.

Berdasarkan observasi yang dilakukan di TK Baiturrahman, tidak semua guru menguasai semua jenis keterampilan mengajar. Banyak faktor yang dapat mempengaruhi guru sehingga kurang maksimal dalam menguasai keterampilan mengajar, baik faktor internal maupun faktor eksternal. Terkait faktor internal, kurangnya keterampilan mengajar guru dapat dilihat dari kurang tepatnya guru dalam merencanakan perangkat pembelajaran, serta kurang mampu menyisipkan/ menggunakan beberapa keterampilan dalam suatu materi pelajaran tertentu sehingga kurang nampak menggunakan keterampilan mengajar. Sedangkan faktor eksternal meliputi kurangnya pelatihan dalam melaksanakan keterampilan mengajar. Salah satu keterampilan yang harus muncul dalam proses pembelajaran di dalam kelas adalah keterampilan bertanya.

Mulyasa (2013: 70) menyatakan bahwa keterampilan bertanya sangat perlu dikuasai guru untuk menciptakan pembelajaran yang efektif dan menyenangkan, karena hampir setiap tahap pembelajaran guru dituntut untuk mengajukan pertanyaan dan kualitas pertanyaan yang diajukan akan menentukan kualitas jawaban siswa. Hartono (2013: 20) menyatakan pertanyaan yang baik akan mampu menggugah siswa untuk terlibat secara aktif dalam proses pembelajaran. Dampak positif bagi siswa yaitu dapat meningkatkan partisipasi di dalam kelas, meningkatkan daya berpikir, dan memecahkan suatu masalah. Sering dijumpai siswa kurang antusias dan merasa bosan ketika mengikuti pembelajaran.

Dari penjelasan di atas guru yang memahami keterampilan bertanya tidak hanya paham bagaimana memberikan kalimat tanya yang tepat, tetapi juga paham bagaimana menjawab pertanyaan sehingga anak dapat memproses dan menerima jawaban dengan mudah. Dengan pertanyaan yang tepat anak akan tertarik untuk mengetahui lebih jauh lagi mengenai sesuatu yang sedang dibahas. Biasanya ketika anak mulai terangsang berpikir, anak akan terusmenerus bertanya tanpa henti.

Keterampilan merupakan sesuatu yang dimiliki manusia dalam kemampuan terhadap suatu objek, dan bertanya menjadi suatu kemampuan yang ada di dalam diri manusia untuk mendapatkan suatu informasi terhadap sesuatu, hal. Ini menjadi hal penting yang ada di dalam diri manusia agar dapat mengasah rasa ingin tahu dan pengalaman dari suatu jawaban yang ditemukan. Menurut Singer dikutip oleh Anung (2000: 61) keterampilan adalah derajat keberhasilan yang konsisten dalam mencapai suatu tujuan dengan efektif. Sementara, yang dimaksud bertanya adalah salah satu teknik untuk menarik perhatian para pendengarnya, khususnya menyangkut hal-hal penting yang menuntut perhatian dan perlu dipertanyakan (Majid, 2013: 235).

Ada yang mengatakan bahwa "berpikir itu sendiri adalah bertanya". Menurut Hasibuan (2006: 62) keterampilan bertanya adalah ucapan verbal yang meminta respon dari seseorang yang dikenal. Respon yang diberikan dapat berupa pengetahuan sampai dengan hal-hal yang merupakan hasil pertimbangan. Jadi bertanya merupakan stimulus efektif yang mendorong kemampuan berfikir.

Keterampilan bertanya sangat perlu dikuasai guru untuk menciptakan pembelajaran yang efektif dan menyenangkan, karena hampir setiap tahap pembelajaran dituntut untuk mengajukan pertanyaan, dan kualitas pertanyaan yang diajukan guru akan menentukan kualitas jawaban peserta didik. Menurut Djamarah (2000: 107) dalam bukunya yang berjudul "Guru dan Anak Didik dalam Interaksi Edukatif", menjelaskan tujuan 
keterampilan bertanya antara lain: 1). Untuk meningkatkan perhatian dan rasa ingin tahu anak terhadap topic; 2). Memfokuskan perhatian pada suatu konsep masalah tertentu; 3). Mengembangkan belajar secara aktif; 4). Mendiagnosis kesulitan belajar anak; dan 5). Mengembangkan kemampuan berfikir anak.

Dari penjelasan di atas, adanya tujuan keterampilan bertanya adalah untuk lebih meningkatkan perhatian anak dalam mengembangkan rasa ingin tahu anak dan mengembangkan kemampuan berfikir anak dalam tanya jawab kepada guru. Terkait dengan keterampilan bertanya, Usman (2006: 75) memberikan dasar-dasar pertanyaan yang baik yang harus diperhatikan, diantaranya: jelas dan mudah untuk dimengerti; diberikan informasi yang cukup untuk menjawab pertanyaan; difokuskan pada suatu masalah atau tugas tertentu; membagi pertanyaan secara merata; memberikan respon yang ramah dan menyenangkan sehingga timbul keberanian siswa untuk menjawab atau bertanya; dan menuntun siswa agar dapat menemukan jawaban yang benar.

Di dalam pengajuan atau pemberian pertanyaan, guru juga harus memperhatikan prinsip-prinsip pokok keterampilan bertanya. Menurut Rusman (2011: 83-84) Prinsip-prinsip pokok keterampilan bertanya yang harus diperhatikan guru antara lain: 1). Berikan pertanyaan secara hangat dan antusias kepada anak di kelas; 2). Berikan waktu berpikir untuk menjawab pertanyaan; 3). Berikan kesempatan kepada yang bersedia menjawab terlebih dahulu; 4). Tunjuk peserta didik untuk menjawab setelah diberikan waktu untuk berpikir; dan 5). Berikan penghargaan atas jawaban yang diberikan.

Pada dasarnya manusia memiliki kemampuan dalam bertanya, baik bertanya secara dasar maupun pertanyaan yang terlihat kritis untuk mendapatkan sebuah jawaban yang tepat. Ada berbagai macam keterampilan bertanya. Sa'ud (2009: 62) membagi keterampilan bertanya menjadi dua yaitu keterampilan bertanya tingkat dasar dan keterampilan bertanya tingkat lanjutan. Keterampilan bertanya dasar dan lanjutan mempunyai perbedaan di antara keduanya. Guru harus lebih memahami pengertian dari keterampilan bertanya dasar dan lanjutan.

\section{Keterampilan Bertanya Dasar}

Bertanya dasar merupakan pertanyaan pertama dan pembuka yang diajukan guru pada awal pembelajaran. Mulyasa (2013: 70) menyatakan keterampilan bertanya dasar mencakup: pertanyaan yang jelas dan singkat, pemberian acuan, pemusatan perhatian, pemindahan giliran, penyebaran pertanyaan, pemberian waktu berpikir, dan pemberian tuntunan. Saat mengajukan pertanyaan guru harus memperhatikan ketepatan dalam pemakaian bahasa supaya bisa diarahkan pada siswa dan pertanyaan harus disusun dengan kata-kata yang sesuai dengan tingkat perkembangan siswa.

Sa'ud (2009: 62) membagi komponenkomponen yaitu bertanya dasar dan lanjutan Adapun komponen bertanya dasar adalah sebagai berikut: 1). Mengungkapkan pertanyaan secara jelas dan singkat; 2). Menggunakan katakata yang mudah dipahami oleh anak sesuai taraf perkembangan; 3). Pemberian acuan Sebelum memberikan pertanyaan guru perlu memberikan acuan pertanyaan berisi informasi yang relevan dengan jawaban yang diharapkan anak. Pemindahgiliran adakalanya satu pertanyaan dijawab lebih dari seorang anak, karena jawaban belum benar atau belum memadai, untuk itu guru perlu menggunakan teknik pemindahan giliran.

\section{Keterampilan Bertanya Lanjutan}

Keterampilan bertanya lanjutan merupakan kelanjutan dari keterampilan bertanya dasar. Biasanya pada sekolah, bertanya lanjutan sudah fokus terhadap pembelajaran atau tema yang diberikan pada hari tersebut. Mulyasa (2013: 74) menyatakan keterampilan bertanya lanjutan yang perlu dikuasai guru meliputi: pengubahan tuntunan tingkat kognitif, peraturan urutan pertanyaan, pertanyaan pelancar, dan peningkatan terjadinya interaksi. Semua itu mengutamakan usaha mengembangkan keterampilan berpikir, memperbesar partisipasi, dan mendorong siswa agar terbiasa melakukan inisiatif belajar.

Berdasarkan pendapat di atas, maka dapat disampaikan bahwa keterampilan bertanya merupakan keterampilan yang sangat penting untuk dikuasai. Hal ini penting karena keterampilan bertanya dapat menciptakan 
suasana belajar yang lebih bermakna di kelas sehingga pembelajaran tidak membosankan. Keterampilan bertanya dapat mengembangkan kemampuan berpikir siswa dalam setiap pembelajaran. Keterampilan bertanya dibagi menjadi dua yang semua itu harus tepat digunakan saat guru mengajar.

Keterampilan bertanya sangat penting dikuasai oleh guru karena hampir semua kegiatan belajar, guru akan lebih sering mengajukan pertanyaan kepada anak. Supaya anak dapat lebih aktif dan dapat lebih memahami apa yang telah disampaikan oleh guru.

Pertanyaan yang baik dilihat dari isi, tetapi cara mengajukan pertanyaan yang tidak sesuai, akan mengakibatkan tidak tercapainya tujuan yang diinginkan oleh guru. Menurut Hasibuan (2006: 19-20) Faktor-faktor yang harus diperhatikan dalam mengajukan pertanyaan antara lain:

1. Kejelasan dan kaitan pertanyaan

Pertanyaan hendaknya diajukan dengan jelas, serta nampak kaitannya antara jalan pikiran yang satu dengan yang lain. Hindari kebiasaan-kebiasaan yang tidak bagus dalam bertanya.

2. Kecepatan dan selang waktu

Usahakan menyampaikan pertanyaan dengan jelas serta tidak tergesa-gesa. Begitu pertanyaan selesai diucapkan, berhentilah sejenak untuk memberi kesempatan kepada siswa untuk berpikir; sementara itu, sambil memonitor kelas, apakah sudah ada yang siap menjawab.

3. Arah dan distribusi penunjukkan

Pertanyaan hendaknya diajukan ke seluruh kelas. Sesudah diberi kesempatan berpikir, barulah menunjuk seseorang untuk menjawabnya. Diusahakan agar pertanyaan didistribusikan secara merata ke seluruh kelas.

4. Teknik reinforcement

Dimaksudkan untuk menimbulkan sikap yang positif pada anak serta meningkatkan prestasi anak dalam kegiatan belajarmengajar sehingga memungkinkan tercapainya tujuan belajar yang lebih baik.

5. Teknik menuntun dan menggali (prompting and probing)

Berdasarkan pernyataan di atas bahwa aspek teknik bertanya harus digunakan dan dilatih, agar guru dapat menggunakan pertanyaan secara efektif dalam proses belajar-mengajar.

Berdasarkan observasi yang dilakukan di TK Baiturrahman, terlihat masih rendahnya penguasaan guru dalam keterampilan bertanya. Hal tersebut dibuktikan dengan kegiatan pembelajaran yang berpusat pada guru. Anak tidak aktif dalam kegiatan belajar. Anak tidak dirangsang untuk menemukan pengetahuannya sendiri melainkan hanya mengikuti apa yang disuruh oleh guru. Anak tidak diberi kesempatan untuk bertanya, sehingga anak yang awalnya mulai ingin mengembangkan proses berpikirnya malah terhenti karena kurangnya pemahaman guru mengenai keterampilan bertanya. Pentingnya guru menguasai keterampilan bertanya menjadi dasar untuk dilakukan penelitian dengan sub fokus sebagai berikut:

1. Bagaimana penguasaan keterampilan bertanya pada guru di TK Baiturrahman?

2. Apa saja hambatan guru dalam penguasaan keterampilan bertanya di TK Baiturrahman?

Tujuan umum penelitian ini untuk mendeskripsikan penguasaan keterampilan bertanya pada kemampuan guru di TK

1. Mengetahui penguasaan keterampilan bertanya pada guru di TK Baiturrahman.

2. Mengetahui hambatan guru dalam penguasaan keterampilan bertanya di TK Baiturrahman.

\section{METODE PENELITIAN}

Penelitian dilakukan di Taman Kanak-Kanak yang ada di Wilayah Jakarta Selatan. Kecamatan Pancoran, yaitu di Taman KanakKanak Baiturrahman. Waktu penelitian ini dimulai dari 21 Januari 2019 sampai 31 Januari 2019. Subjek dalam penelitian ini adalah guru kelas di TK Baiturrahman. Subjek penelitian terdiri dari 3 (tiga) guru kelas A, B1, dan B2.

Berdasarkan permasalahan yang diteliti yaitu tentang penguasaan keterampilan bertanya guru TK, maka penelitian ini menggunakan metode penelitian kualitatif. Digunakannya metode penelitian ini adalah agar diperoleh data pada kondisi yang alamiah, dengan peneliti sebagai instrumen kunci pengambilan data, melakukan triangulasi terhadap data serta analisis data secara induktif dengan pendekatan makna. 
Denzin dan Lincoln (dalam Moleong, 2011: 5) mengatakan bahwa penelitian kualitatif adalah penelitian yang menggunakan latar alamiah, dengan maksud menafsirkan fenomen yang terjadi dan dilakukan dengan jalan melibatkan berbagai metode yang ada.

Pendekatan yang peneliti gunakan adalah pendekatan kualitatif deskriptif yaitu pendekatan penelitian yang dimaksudkan untuk menjelaskan fenomena atau karakteristik individu, situasi atau kelompok tertentu secara akurat. Pendekatan kualitatif deskriptif ini hanya dengan membuat deskripsi atau narasi dari suatu fenomena tidak untuk mencari hubungan antar variabel, ataupun menguji hipotesis. Menurut Moleong (2011: 11) Pendekatan kualitatif deskriptif adalah data yang dikumpulkan berupa kata-kata, gambar, dan bukan angka. Laporan penelitian akan berisi kutipan-kutipan data untuk memberi gambaran penyajian laporan tersebut. Jenis pendekatan penelitian ini bertujuan untuk memberi gambaran secara terperinci mengenai suatu gejala sosial tertentu yaitu untuk mendapatkan suatu gambaran mengenai penguasaan keterampilan bertanya pada kemampuan guru Taman Kanak-kanak.

Sumber data penelitian ini disesuaikan dengan tujuan diadakannya penelitian. Menurut Arikunto (2006), secara garis besar sumber data penelitian dibedakan menjadi dua macam yaitu:

\section{Sumber Data Primer/ Pokok}

Data primer adalah sumber data yang pertama. Dari subjek atau objek penelitianlah data penelitian langsung diambil (Dimyati, 2013: 39). Pada penelitian ini peneliti akan meneliti penguasaan keterampilan bertanya pada kemampuan guru. Peneliti mengadakan observasi langsung terhadap aktivitas kegiatan pelaksaan penguasaan keterampilan bertanya pada kemampuan guru di kelompok A, B1, dan B2 TK Baiturrahman. Maka sumber data primernya yaitu:

Tabel 1. Sumber data primer

\begin{tabular}{clc}
\hline No & \multicolumn{1}{c}{ Informan } & Jumlah \\
\hline 1 & Kepala TK Baiturrahman & 1 Orang \\
\hline 2 & Guru kelas A & 1 Orang \\
\hline 3 & Guru kelas B1 & 1 Orang \\
\hline
\end{tabular}

\begin{tabular}{cll}
\hline 4 & Guru kelas B2 & 1 Orang \\
\hline 5 & Guru pendamping B1 & 1 Orang \\
\hline 6 & Guru Pendamping B2 & 1 Orang \\
\hline
\end{tabular}

\section{Sumber Data Sekunder/ Pelengkap}

Data sekunder adalah sumber data yang bisa diambil dari pihak mana saja yang bisa memberikan tambahan data guna melengkapi kekurangan dari data yang diperoleh melalui sumber data primer (Dimyati, 2013: 40). Untuk melengkapi identitas atau dokumen guru, maka peneliti menggunakan sumber data sekunder yang berupa dokumentasi. Untuk melengkapi data tentang penguasaan keterampilan bertanya pada kemampuan guru maka peneliti mewawancara kepala sekolah, guru kelas dan guru pedamping.

Metode pengumpulan data dalam penelitian kualitatif yang terpenting untuk digunakan adalah: wawancara, observasi, dan dokumentasi.

\section{Wawancara}

Wawancara adalah bentuk komunikasi antara dua orang, melibatkan seseorang yang ingin memperoleh informasi dari seorang lainnya dengan mengajukan pertanyaan-pertanyaan berdasarkan tujuan tertentu (Mulyana, 2010: 180). Wawancara merupakan percakapan yang dilakukan oleh dua pihak, yaitu pewawancara (interviewer) yang mengajukan pertanyaan dan terwawancara (interviewee) yang memberikan jawaban atas pertanyaan. Di dalam penelitian ini wawancara dilakukan oleh peneliti sebagai instrumen penelitian dan subjek penelitian dengan bercakap-cakap secara tatap muka dan pada penelitian ini wawancara akan dilakukan dengan menggunakan pedoman wawancara.

\footnotetext{
Wawancara yang dilakukan merupakan wawancara terstruktur, yaitu kegiatan wawancara yang di dalamnya sudah disiapkan instrumen penelitian berupa pertanyaanpertanyaan tertulis yang alternatif jawabannya pun telah disiapkan. Peneliti memilih wawancara terstruktur karena informasi yang didapatkan lebih mudah, dimana penulis sudah menyiapkan pertanyaan-pertanyaan yang akan ditanyakan secara rinci.
} 
Adapun data yang dihasilkan dari wawancara dimasukkan ke dalam kategori kode catatan. CWK untuk hasil wawancara kepala sekolah TK, CWG1 untuk hasil wawancara dengan guru kelas A1, CWG2 untuk hasil wawancara guru kelas B1, CWG3 untuk hasil wawancara dengan guru kelas B2, dan CWP untuk hasil wawancara dengan guru pendamping.

\section{Observasi}

Observasi adalah pengamatan dan pencatatan dengan sistematis fenomena-fenomena yang diteliti (Hadi, 2004: 151). Di dalam penelitian ini teknik observasi digunakan untuk melengkapi data yang peneliti inginkan, agar data dan informasi yang didapat semakin jelas. Hasil observasi ini sekaligus untuk mengkonfirmasikan data yang telah terkumpul melalui wawancara dengan kenyataan yang sebenarnya.

Menurut Sugiyono (2011: 226), dari segi proses pelaksanaan pengumpulan data, observasi dapat dibedakan menjadi 3 macam yaitu observasi partisipatif, observasi terus terang dan tersamar, dan observasi terstruktur. Pada observasi ini peneliti memilih partisipasi pasif (passive participation). Peneliti memilih observasi partisipasi pasif karena peneliti hanya mengamati dan mencatat apa yang terjadi di lapangan, dan peneliti juga harus menaati peraturan-peraturan pada sekolah yang diobservasi yaitu sekolah meminta untuk tidak ikut serta dalam kegiatan yang akan diteliti dan observer hanya boleh mengamati dan mencatat saja. Ketika observasi peneliti berada di dalam satu ruangan dengan subjek penelitian namun peneliti hanya melihat dan mengamati apa yang ingin dicatat dan didokumentasikan tanpa menggangu anak didik dan guru.

\section{Dokumentasi}

Dokumentasi merupakan catatan peristiwa yang berbentuk tulisan, gambar, atau karya monumental dari seseorang (Gunawan, 2012: 176). Dokumentasi digunakan untuk memperkuat data-data yang sudah ada seperti hasil data dari wawancara dan observasi.

Alat komunikasi yang digunakan saat mendokumentasikan hasil observasi adalah kamera dan HP. Adapun data dari hasil dokumentasi yang didapat oleh peneliti berupa arsip-arsip yang meliputi data tentang pelaksanaan kegiatan keterampilan bertanya, seperti data tentang kegiatan di dalam kelas, foto maupun video kegiatan di dalam kelas yang dilakukan terkait penelitian. Adapun data yang diperoleh dari hasil studi dokumentasi ini diberi kode catatan dokumentasi (CD).

\section{HASIL DAN PEMBAHASAN}

\section{Profil TK Baiturrahman}

TK Baiturrahman berada di bawah naungan Yayasan Bait Al Rahman. TK Baiturrahman berdiri pada 1 Juni 1982. Sebelum adanya TK di Yayasan Bait Al-Rahman sudah berdiri terlebih dahulu Madrasah Ibtidaiyah (MI) sejak tahun 1972. Setelah MI, Yayasan Bait Al Rahman mendirikan Taman Kanak - Kanak pada tahun 1982, kemudian Yayasan Bait Al Rahman mendirikan kembali Sekolah Menengah Pertama (SMP) pada tahun 2005, maka Yayasan Bait Al Rahman mempunyai 3 bidang pendidikan yaitu TK, MI dan SMP. (CWK)

TK Baiturrahman berada di jalan Duren Tiga Selatan VII RT 004 RW 002 Kelurahan Duren Tiga, Kecamatan Pancoran, Kota Jakarta Selatan. Letak tersebut sangat strategis dan sangat mudah diakses dengan kendaraan pribadi maupun kendaraan umum, yaitu TK Baiturrahman bertempat di pinggir jalan sehingga mudah untuk dicari. TK Baiturrahman memiliki fasilitas yang terkait dengan kelancaran dan keefektifan proses belajar mengajar yang berupa:

Tabel 2. Fasilitas Sekolah TK Baiturrahman

\begin{tabular}{|c|c|c|}
\hline \multirow{2}{*}{ Jenis Fasilitas } & \multicolumn{2}{|c|}{ Berfungsi } \\
\hline & Ya & Tidak \\
\hline $\begin{array}{l}4 \text { kelas dengan } \\
\text { sirkulasi udara baik }\end{array}$ & $\checkmark$ & \\
\hline Ruang kantor & $\checkmark$ & \\
\hline Aula & $\checkmark$ & \\
\hline Lapangan & $\checkmark$ & \\
\hline
\end{tabular}

Adapun visi TK Baiturrahman adalah membentuk anak yang cerdas, ceria dan berakhlak mulia. Selanjutnya misi TK Baiturrahman adalah menanamakan agama sejak dini, membiasakan membaca dan 
memahami Al-Qur'an, membiasakan berakhlak mulia, membiasakan berperilaku sehat dan menciptakan lingkungan yang aman, nyaman dan menyenangkan (CWK)

TK Baiturrahman memiliki rombongan sebanyak 3 (tiga) kelas yang terdiri dari 1 (satu) kelas A, dan 2 (dua) kelas kelompok B. Pembagian kelas tersebut terbagi menjadi 1 (satu) kelompok A, dan 2 (dua) kelompok B. Untuk kelompok A memiliki 1 orang guru kelas, dan untuk kelompok B memiliki 2 orang guru dan bahasa pengantarnya adalah Bahasa Indonesia. Hari efektif sekolah di TK Baiturrahman adalah 5 hari yaitu Senin, Selasa, Rabu, Kamis, dan Jumat. Adapun jam masuk setiap kelompok tertuang dalam tabel 3:

Tabel 3. Jam masuk kelompok A \& B TK Baiturrahman

\begin{tabular}{lc}
\hline Kelompok & Jam Masuk \\
\hline Kelompok A & $08.00-10.30$ \\
\hline Kelompok B & $08.00-11.00$ \\
\hline
\end{tabular}

\section{Kurikulum Sekolah}

Kurikulum yang diterapkan di TK Baiturrahman merupakan perpaduan antara Kurikulum 2013 yang tercantum dalam Peraturan Menteri Pendidikan dan Kebudayaan Nomor 146 Tahun 2014 tentang Kurikulum PAUD dan Peraturan Menteri Pendidikan dan Kebudayaan Nomor 137 Tahun 2014 tentang Standar PAUD serta muatan lokal sebagai ciri khas pendidikan yang dikembangkan oleh TK Baiturrahman. Kurikulum ini adalah sebagai acuan yang akan menjadi pedoman pelaksanaan proses pembelajaran sehingga diharapkan pembelajaran berlangsung efektif, mampu membangkitkan kreatifitas, serta aktifitas yang menyenangkan dan mengasyikkan bagi peserta didik. Kurikulum akan menjadi pedoman yang dinamis sifatnya bagi penyelenggaraan dan pengajaran di TK Baiturrahman. (CWK)

Berikut dipaparkan hasil penelitian dari 3 subjek penelitian.

\section{Subjek penelitian 1}

1. Kegiatan Pembuka

Pembelajaran dimulai pada pukul 08.00 yang diawali dengan kegiatan pembuka dengan memberi salam, menanyakan kabar anak, dan dilanjutkan dengan membaca surat Al-Fatihah, surat pendek, hadits dan doa-doa harian. Setelah selesai pembacaan doa, guru M mengajak anak untuk bertepuk rukun Islam dan rukun Iman. Setelah kegiatan pembuka selesai, guru M langsung melanjutkan ke kegiatan inti.

\section{Kegiatan Inti}

Kegiatan inti diawali dengan guru menanyakan tentang Pancasila dan semua anak diajak berdiri untuk menyebutkan Pancasila. Setelah menyebutkan Pancasila, guru M menanyakan kepada anak mengenai warna Bendera Indonesia dan semua anak menjawab merah dan putih, setelah itu guru mulai mengajak anak menyanyikan lagu Indonesia Raya. Selanjutnya anak diajak kembali duduk, dan guru $M$ menanyakan tentang jalan-jalan ke desa, "siapa yang pernah jalan-jalan ke desa?" dan semua anak menjawab sambil mengangkat tangan "Saya Bu" (CWG-A: 1)

Guru M kembali menanyakan "siapa yang mempunyai kampung halaman?", guru M sejenak terdiam menunggu jawaban anak dan guru $\mathrm{M}$ menunjuk anak yang berinisal J. J menjawab"Punya Bu di Jawa" dan guru M menunjuk kembali anak yang berinisial $\mathrm{N}$ dan $\mathrm{N}$ hanya terdiam dan tidak menjawab. Guru $\mathrm{M}$ pun bicara "Ayo N punya kampung tidak?" dan $\mathrm{N}$ pun masih terdiam dan guru $\mathrm{M}$ melanjutkan cerita dengan cerita kampung halaman guru $\mathbf{M}$ sendiri dan anak hanya terdiam dan sibuk dengan dunianya sendiri (CWG-A: 2-3-4) Setelah guru $M$ selesai bercerita, guru M lanjut masuk di kegiatan anak yaitu memberikan buku tugas dan kegiatan yang diberikan anak hanya satu.

\section{KegiatanPenutup}

Pada saat kegiatan penutup, setelah anak selesai makan, anak diajak membaca doa pulang dan dipersilakan memakai sepatu dan menunggu jemputan.

\section{Subjek penelitian 2}

1. Kegiatan Pembuka

Pada pukul 08.00 WIB bel berbunyi, anak anak masuk ke dalam kelas untuk melakukan shlat dhuha bersama-sama. Setelah anak mambuka sepatu dan kaos kaki anak melakukan wudhu sebelum shalat dhuha. Setelah anak semua berwudhu, anak perempuan memakai 
mukena dan sarung untuk anak laki-laki. Sebelum shalat dimulai guru $\mathrm{N}$ menanyakan "berapa rokaat shalat dhuha?", dan semua anak menjawab "2 rakaat" setelah itu anak niat shalat dhuha dan melanjutkan shalat bersamasama. Setelah shalat dhuha selesai semua anak diajak membaca doa kedua orang tua, anak boleh merapikan muena dan sarung, kemudian ditaruh di loker anak masing-masing. Selanjutnya anak diajak duduk membuat lingkaran untuk membaca doa. Sebelum membaca doa, guru $\mathrm{N}$ mengabsen anak dengan cara bernyanyi "kalau kau suka hati" dengan menyebutkan nama anak. Setelah selesai bernyanyi, guru $\mathrm{N}$ memulai membaca doa dengan surat al fatihah, surat - surat pendek, doa - doa pendek, dan hadis.

Setelah selesai berdoa, guru $\mathrm{N}$ menanyakan kepada anak hari dan tanggal berapa sekarang dan hanya beberapa anak yang menjawab, setelah itu guru $\mathrm{N}$ memberi tahu tema hari ini adalah "Petani" dan guru $\mathrm{N}$ memberikan pertanyaan kembali ke pada anak "siapa pak tani itu?", guru $\mathrm{N}$ sejenak berdiam untuk mendengar jawaban dari anak. Anak yang berinisial M menjawab "orang yang menggali tanah", dilanjut guru menanyakan kembali, anak yang berinisial $\mathrm{R}$ menjawab "menanam $b u$ ", dan guru langsung memberi jempol ke anak yang berinisial $\mathrm{R}$ karena jawaban $\mathrm{R}$ benar (CWG B1: 1-2). Guru N memberi pertanyaan kembali kepada anak, "siapa yang tahu pak tani menanam padi dimana?", Semua anak terdiam, guru $\mathrm{N}$ menunjuk salah satu anak berinisial $\mathrm{D}$, ternyata $\mathrm{D}$ tidak dapat menjawab. Guru langsung menanyakan kembali ke anak berinisial $M$ dan $M$ terdiam dan $M$ langsung menjawab "di sawah". Guru mengulang kembali pertanyaan "dimana pak tani menanam padi?" dan semua anak "membajak sawah" guru M memberi pujian kepada anak dengan mengucapkan anak hebat (CWG B1: 3-4-5-6) Setelah penjelasan tema di kegiatan pembuka, guru melanjutkan ke kegiatan inti.

\section{Kegiatan Inti}

Kegiatan inti diawali dengan guru $\mathrm{N}$ menanyakan kembali hari dan tanggal sebelum kegiatan inti dimulai. Setelah anak memperhatikan guru, guru $\mathrm{N}$ kembali menanyakan kepada anak, "pak tani memakai topi, ada yang tau apa nama topi pak tani?", tetapi semua anak tidak dapat menjawab pertanyaan yang guru $\mathrm{N}$ tanyakan. Akhirnya guru $\mathrm{N}$ menawab pertanyaan sendiri yaitu caping. Guru N kembali bertanya, "apa bentuk topi pak tani?", sambil menunjukkan gambar di papan tulis dan semua anak menjawab, "segi tiga". Setelah itu guru N menjelaskan kegiatan inti yaitu kegiatan pertama kolase dengan menggunakan origami, kegiatan ke dua memberi tanda ceklis (v) dan tanda silang ( $\mathrm{x}$ ), dan kegiatan ke tiga menulis di buku tulis kalimat "petani".

\section{Kegiatan Penutup}

Pada saat kegiatan penutup, setelah anak selesai makan dan membaca doa pulang, guru kembali menanyakan tema hari ini kepada anak dan semua anak menjawab. Guru menanyakan, "kegiatan hari ini ada berapa kegiatan?" dan semua anak menjawab, "ada tiga kegiatan". Guru menunjuk anak berinisial K, "kegiatan pertama apa?", dan K menjawab "menempel". Guru kembali menanyakan kegiatan ke dua kepada anak yang berinisial $\mathrm{S}$ ternyata $\mathrm{S}$ tidak dapat menjawab dan guru kembali menunjuk A. Anak berinsial A menjawab "memberi tanda dengan menggerakan tangannya (centang)" dan kegiatan ke tiga guru menanyakan ke semua anak dan semua anak menjawab menulis "petani". Setelah pertanyaan dapat dijawab oleh anak, guru $\mathrm{N}$ memanggil satu-satu anak untuk memakai sepatu dan diizinkan pulang (CWG B1, C4).

\section{Subjek penelitian 3}

\section{Kegiatan Pembuka}

Pada pukul 08.00 WIB bel berbunyi, anak anak masuk ke dalam kelas untuk melakukan shalat dhuha bersama-sama. Setelah anak mambuka sepatu dan kaos kaki, anak melakukan wudhu kemudian memakai mukena untuk anak perempuan dan sarung untuk anak laki-laki. Sebelum shalat di mulai guru $\mathrm{S}$ menanyakan, "berapa rokaat shalat dhuha?" dan semua anak menjawab "2 rakaat". Setelah itu anak niat shalat dhuha dan melanjutkan shlat bersama-sama. Setelah shalat dhuha selesai, semua anak diajak membaca doa kedua orang tua, merapikan munkena dan sarung, dan meletakkan di loker anak masing-masing. Setelah selesai shalat dhuha dan merapihkan mukena anak diajak duduk membuat lingkaran untuk membaca doa, yang diawali dengan mengabsen anak dengan cara berhitung menggunakan bahasa Inggris. Setelah selesai absen, guru $\mathrm{S}$ memulai membaca doa dengan 
surat al fatihah, surat - surat pendek, doa - doa pendek, dan hadis.

\section{Kegiatan Inti}

Guru S mengajukan pertanyaaan, "siapakah yang memberikan rizki?, serentak seluruh anak menjawab, "Allah". Guru S menjelaskan bahwa setiap manusia memang memiliki pekerjaan yang berbeda-beda namun rezeki manusia hanya Allah yang memberinya. Guru $S$ memberikan selembar kertas yang berisi 3 buah gambar profesi. Gambar pertama yaitu polisi, "apa tugas pak polisi? Anak menjawab, "pak polisi tugasnya adalah menangkap penjahat", kata si C. Kemudian D ada juga yang menjawab "pak polisi tugasnya mengatur lalu lintas". Sementara F menjawab, "tugas pak polisi mengantar seseorang yang tersasar". Guru S menjelaskan secara detail bahwa tugas pak polisi adalah menjaga keamanan lingkungan di tempat kita tinggal bahkan pak polisi juga menjaga keamaan di negri ini (CWG B2: 1)

Guru S kembali bertanya, "pak polisi ketika bertugas membawa apa yah?". Anak menjawab, "pak polisi membawa pistol dan peluit". Selain itu guru S juga meniru gerakan pak polisi yang menjelaskan bahwa kendaraan harus berhenti dan kendaraan harus melintas. Sebagai penjelasan guru S memberikan ilustrasi jalanan yang bergaris-garis layaknya hewan zebra dinamakan Zebracross yang berfungsi untuk para pejalan kaki yang akan menyebrang. Bila tidak ada, maka tugas pak polisi untuk membantunya. Selain itu, pak polisi juga bertugas menilang pengendara baik motor atau mobil yang melanggar lalu lintas dan tidak memiliki Surat Izin Mengendara (SIM). Guru S bertanya, "apa nama dan fungsi lampu rambu lalu lintas?". Seluruh anak menjawab, "Merah berhenti Hijau jalan", dan menjadi perdebatan diantar anak mengenai lampu yang berwarna kuning. Sebagian menjawab lampu kuning hatihati dan yang lainnya menjawab lampu kuning pelan-pelan.

Dari hasil penjelasan yang diberikan oleh guru $\mathrm{S}$ maka timbullah pertanyaan dari salah satu anak, "ibu guru bila hujan turun apakah pak polisi tetap bertugas?", Guru S menjawab "Iya, walaupun cuaca hujan namun pak polisi tetap menjalankan tugasnya dengan baik".

Setelah penjelasan tema tentang pekerjaan, guru $\mathrm{S}$ melanjutkan dengan kegiatan anak. Guru S memberikan 2 kegiatan, yang pertama menuliskan kalimat "Pak Polisi" sebanyak 5 kali dan kegiatan kedua menjumlahkan gambar yang ada di buku pembelajaran.

\section{Kegiatan Penutup}

Pada saat kegiatan penutup setelah anak selesai makan, guru mulai menyanyikan lagu pulang sekolah sambil mengarahkan anak membuat lingkaran. Setelah anak siap berdoa, guru memimpin doa pulang sekolah dengan membaca doa sesudah makan, surat al asr', doa keluar kelas dan doa naik kendaraan. Setelah selesai berdoa, guru S mengajak anak bermain berpacu dalam menebak. Disini anak diajak oleh guru $\mathrm{S}$ untuk menjawab pertanyaan kepada anak. Satu anak satu pertanyaan, ketika anak bisa menjawab anak dipersilakan keluar kelas (CWG B2: C4)

Keterampilan bertanya sangat perlu dikuasai guru untuk menciptakan pembelajaran yang efektif dan menyenangkan, karena hampir setiap tahap pembelajaran guru dituntut untuk mengajukan pertanyaan dan kualitas pertanyaan yang diajukan akan menentukan kualitas jawaban anak. Hal ini sebagaimana yang dikatakan oleh Mulyasa (2013: 70), keterampilan bertanya yang diberikan oleh guru kelompok A TK Baiturrahman, hanya diberikan pada saat inti pembelajaran, sedangkan guru kelompok B memberikan keterampilan bertanya di setiap tahap pembelajaran.

Menurut Sa'ud (2009: 62), Keterampilan bertanya terbagi menjadi dua yaitu keterampilan bertanya tingkat dasar dan keterampilan bertanya tingkat lanjutan. Keterampilan bertanya dasar dan lanjutan mempunyai perbedaan di antara keduanya. Guru harus lebih memahami pengertian dari keterampilan bertanya dasar dan lanjutan.

Di dalam keterampilan bertanya dasar terdapat 6 komponen, mengungkapkan pertanyaan secara jelas dan singkat guru kelompok A dan B mengungkapkan pertanyaan secara jelas dan singkat seperti: "Siapa pak tani?". Dalam pemberian acuan, guru kelompok A tidak memberikan acuan sebelum memberikan pertanyaan, sedangkan guru kelompok B memberikan acuan seperti media gambar, pemindahan giliran guru kelompok A dan B dengan cara menunjuk anak yang dipersilakan menjawab. Terkait penyebaran giliran, guru 
kelompok A dan B memberikan kesempatan kepada semua anak untuk menjawab pertanyaan yang diberikan. Kemudian, pemberian waktu berfikir, guru kelompok A dan B berdiam sejenak untuk memberikan waktu berfikir anak, sementara dalam pemberian tuntunan, guru kelompok A dan B tidak memberikan tutntunan ketika anak menjawab salah.

Terdapat 4 komponen bertanya lanjutan yaitu: pengubahan tingkat kognitif. Terkait hal tersebut, guru kelompok A dan B memberikan pengubahan tingkat kognitif seperti memberikan pertanyaan "Siapa pak polisi?" dan "Apa pekerjaan pak polisi?". Untuk mengurutkan pertanyaan yang diajukan, guru kelompok A dan B sudah melakukan pengurutan pertanyaan seperti siapa dan apa.

Melacak pertanyaan sebagai bagian dari komponen bertanya lanjutan, guru kelompok A belum menerapkan sedangkan guru kelompok B sudah menerapkan pada saat kegiatan inti. Terakhir mendorong terjadinya interaksi, guru kelompok A sudah terjadi pada saat kegiatan inti sampai penutup, sedangkan guru kelompok B interaksi dimulai dari kegiatan pembuka, kegiatan inti dan kegiatan penutup.

Adapun hambatan yang dialami guru dalam keterampilan bertanya yaitu guru kelompok A tidak mengetahui apa saja aspek-aspek pertanyaan yang ada karena guru kelompok A mengajar hanya mengandalkan pengalaman. Sedangkan guru kelompok B hanya mengetahui beberapa aspek keterampilan bertanya dan guru kelompok B tidak menguasai tentang jenis-jenis pertanyaan dan teknik-teknik bertanya.

\section{SIMPULAN DAN SARAN}

Berdasarkan hasil penelitian maka peneliti memberikan kesimpulan sebagai berikut: pertama, keterampilan bertanya guru di TK Baiturrahman tidak sepenuhnya dikuasai. Keterampilan bertanya di TK Baiturrahman lebih banyak menggunakan keterampilan bertanya dasar, dengan komponen: mengungkapkan pertanyaan jelas dan singkat; memberikan acuan sebelum memberikan pertanyaan; pemindahan giliran; menyebarkan giliran; pemberian waktu berfikir; dan pemberian tuntunan jika anak menjawab salah.
Kedua, terkait hambatan yang dialami guru dalam penguasaan keterampilan bertanya di TK Baiturrahman berbeda-beda. Hambatan yang dialami berupa tidak mengetahui tentang apa saja aspek-aspek pertanyaan yang termasuk dalam keterampilan bertanya; hanya mengetahui beberapa aspek keterampilan bertanya; serta tidak menguasai tentang jenisjenis pertanyaan dan teknik-teknik bertanya.

Berdasarkan hasil penelitian dan kesimpulan tersebut, maka saran yang dapat diberikan yaitu: pertama, Dalam keterampilan bertanya disarankan agar guru dapat mendalami tentang aspek jenis-jenis pertanyaan dan teknik-teknik bertanya agar anak dapat lebih memahami pada saat kegiatan pembelajaran berlangsung; kedua, disarankan agar guru menambah pengetahuan dan pemahaman mengenai keterampilan bertanya dengan mengikuti seminar, diskusi, ataupun membaca referensi terkait.

\section{DAFTAR PUSTAKA}

Arikunto. (2006). Metode penelitian kualitatif. Jakarta: Bumi Aksara.

Djamarah, S.B. (2010). Guru dan anak didik dalam interaksi edukatif: suatu pendekatan teoritis psikologis. Jakarta: Rineka Cipta.

Gunawan. (2012). Metode penelitian kualitatif teori dan praktik. Jakarta: Bumi Aksara.

Hartono, R. (2013). Ragam model mengajar yang mudah diterima murid. Yogyakarta: Diva Press.

Hasibuan. (2006). Proses belajar mengajar. Bandung: PT. Remaja Rosdakarya.

Majid, A. (2013). Strategi pembelajaran. Bandung: PT. Remaja Rosdakarya.

Usman, M.U. (2006). Menjadi guru profesional. Bandung: PT. Remaja Rosdakarya.

Moleong, L.J. (2011). Metodologi penelitian kualitatif. Bandung: Remaja Rosdakarya.

Mulyana, (2010). Metodologi penelitian kualitatif. Bandung: PT. Remaja Rosdakarya

Mulyasa. (2013). Menjadi guru profesional menciptakan pembelajaran kreatif \& menyenangkan. Bandung: Remaja Rosdakarya.

Peraturan Menteri Pendidikan dan Kebudayaan Nomor 146 tahun 2014 
Rusman. (2011). Model-model pembelajaran: mengembangkan profesionalisme guru. Jakarta: Raja GrafindoPersada.

Sa'ud, S.U. (2009). Pengembangan profesi guru. Bandung: Alfabeta.

Sugiyono, (2011). Metode penelitian kuantitatif, kualitatif dan R\&D. Bandung: Afabeta.
Sukirman, D. (2012). Pembelajaran micro. Bandung: UPI Press.

Undang - Undang Republik IndonesiaNomor 14 Tahun 2005 tentang guru dan dosen. Jakarta: Sinar Grafika. 